\title{
Biophysical and microbiological study of high hydrostatic pressure inactivation of Bovine Viral Diarrheavirus type 1 on serum
}

\author{
Cagatay Ceylan a,*, Feride Severcan ${ }^{\mathrm{b}}$, Aykut Ozkul $^{\mathrm{c}}$, Mete Severcan ${ }^{\mathrm{d}}$, Faruk Bozoglu ${ }^{\mathrm{e}}$, \\ Nusret Taheri ${ }^{\mathrm{f}}$
}

${ }^{a}$ Department of Food Engineering, Izmir Institute of Technology, Urla, 35430 Izmir, Turkey

${ }^{\mathrm{b}}$ Department of Biological Sciences, Middle East Technical University, Ankara, Turkey

${ }^{\mathrm{c}}$ Virology Department, Faculty of Veterinary Medicine, Ankara University, Ankara, Turkey

${ }^{\mathrm{d}}$ Department of Electrical Engineering, Middle East Technical University, Ankara, Turkey

${ }^{\mathrm{e}}$ Department of Food Engineering, Middle East Technical University, Ankara, Turkey

${ }^{\mathrm{f}}$ Medical Center, Middle East Technical University, Ankara, Turkey

\section{A R T I C L E I N F O}

\section{Article history:}

Received 4 May 2011

Received in revised form 12 July 2011

Accepted 21 July 2011

\section{Keywords:}

Fetal bovine serum (FBS)

High hydrostatic pressure (HHP)

Fourier transform infrared spectroscopy (FTIR)

Artificial neural networks (NN)

Virus

\begin{abstract}
A B S T R A C T
The effect of high hydrostatic pressure application on fetal bovine serum components and the model microorganism (Bovine Viral Diarrheavirus type 1 NADL strain) was studied at 132 and $220 \mathrm{MPa}$ pressure for $5 \mathrm{~min}$ at $25^{\circ} \mathrm{C}$. Protein secondary structures were found to be unaffected by an artificial neural network application on the amide I region for both untreated and HHP treated samples. FTIR spectroscopy study of both the HHP-treated and control samples revealed changes in the intensity of some bands in the finger-print region (1500-900 $\mathrm{cm}^{-1}$ ) originating mainly from lipids which are thought to result from changes in the lipoprotein structure. The virus strain lost its infectivity completely after $220 \mathrm{MPa}$ HHP treatments. These results indicate that HHP can be successfully used for inactivation of pestiviruses while leaving structural and functional properties of serum and serum products unaffected.
\end{abstract}

(c) 2011 Elsevier B.V. All rights reserved.

\section{Introduction}

Serum is the fluid portion of blood after clotting is allowed to occur. It is composed of water, blood proteins and inorganic electrolytes. It serves as a transporting medium for important metabolic substrates and end products in vivo. It is a transporting agent for several pathogens in the case of illness (Beltrami et al., 2000). Commercially, fetal bovinecalf (FBS-FCS) serum is an important component of cell culture studies due to its rich composition. However, the drawback of FBS is that it involves a microbial contamination risk, in particular viral contamination, since it might be obtained from infected animals. A number of studies highlight the presence of fetal-borne pestivirus contamina-

\footnotetext{
* Corresponding author. Tel.: +90 232750 6328; fax: +90 2327506196 E-mail address: cagatayceylan@iyte.edu.tr (C. Ceylan).
}

tion in commercial fetal bovine serum (Nuttall et al., 1977; Makoschey et al., 2003). Pestivirus contamination is also a current problem in our laboratory, which requires testing of each single purchased bottle of FBS.

High hydrostatic pressure (HHP) treatment is used advantageously in many areas due to its isostatic pressure properties (Knorr, 1993). Food processing is one such field where industrial applications of HHP already exist (Tedford et al., 1999; Hayashi, 1995). HHP has been proposed as an alternative technique to thermal processing to destroy foodborne pathogens since it can inactivate or injure microorganisms without altering the flavor and nutrient content of foods, as indicated by Hoover et al. (1989). Moreover, several bacterial and viral inactivation studies have been carried out using HHP treatment (Wuytack et al., 2002; Silva, 1993; Jurkiewicz et al., 1995; Kingsley et al., 2002).

The number of studies on the effect of the HHP treatment on blood or blood components is very limited 
(Matser et al., 2005; Toldra et al., 2008; Ceylan et al., 2009). In one of these studies, the effect of HHP treatment on porcine blood plasma was studied and slight changes in protein solubility and no change in water-holding capacity, hardness and microstructure of the gels obtained from blood plasma were reported when solubility and calorimetric methods were used (Pares et al., 2000). Bradley et al. (2000) studied the effect of pressure cycling technology on the functionality of some proteins in human plasma at nearzero $\left(0^{\circ} \mathrm{C}\right)$ temperatures and found important stabilities after the treatments. They used the lambda phage as the model virus and found that the virus titer was reduced significantly after the treatments. Recently we reported the effects of HHP on the stability of blood constituents using flow cytometry (FC), light and atomic force microscopy (AFM) and Fourier transform infrared (FTIR) spectroscopy. Morphological and molecular changes in macromolecular concentration, lipid peroxidation, lipid order and fluidity, and protein secondary structure were observed in neither red blood cells nor platelets (Ceylan et al., 2009).

In the current study, the possibility of using HHP treatment to eliminate contaminating pestiviruses in serum but at the same time to preserve the structural and functional integrity of serum components was studied via FTIR and microbiologic analyses. Bovine Viral Diarrheavirus type 1 NADL strain (BVDV1) strain was chosen as model virus. BVDV was chosen since it is a major contaminant of several biologicals, including commercial bovine serum preparations and it is a model microorganism for the important blood-borne human pathogen hepatitis $C$ virus (Zitzmann et al., 1999). Fourier transform infrared spectroscopy was used to monitor molecular changes since it is a rapid, sensitive and nondestructive method which is widely used in the analysis of biological systems in any physical state (Dogan et al., 2007; Cakmak et al., 2006, 2011), requires only minute amounts of samples, and allows analysis of the data with many different digital manipulations.

\section{Materials and methods}

\subsection{The serum material}

Fetal bovine serum (Biochrom AG, Germany) preparations were purchased and used throughout the study.

\subsection{The high pressure unit}

The HHP experiments were carried out in a designed and constructed lab-scale unit (capacity $30 \mathrm{~cm}^{3}$ ) high pressure cell, where a mixture of deionized water and glycerol was used as the isostatic pressure transducing medium. The equipment consists of a pressure chamber of cylindrical design, two end closures, a means for restraining the end closures, a pressure pump, and a hydraulic unit to generate high pressure for system compression and also a temperature control device. The pressure vessel was made of hot galvanized carbon steel and the piston was hard chrome plated and polished to mirror finish (steel type heat treated special K) and was processed into the required sizes at the Electrical and Electronic Engineering Department of Middle East Technical University, Ankara,
Turkey. The liquid was heated to the desired temperature prior to pressurization by an electrical heating system surrounding the chamber. The rate of pressure increase and pressure release was approximately $5-10 \mathrm{~s}$ for the designed system. Throughout the experiments, the samples were subjected to HHP treatment for $5 \mathrm{~min}$ at $25^{\circ} \mathrm{C}$. Pressurization times reported in this study did not include the pressure increase and release times. The unit is capable of operating up to $450 \mathrm{MPa}$ pressure between $25^{\circ} \mathrm{C}$ and $95^{\circ} \mathrm{C}$. The samples were dispensed in $2-\mathrm{mL}$ portions in sterile cryovials without any head space (Sterilin, UK). The operation conditions reported in earlier HHP studies were followed (Balasubramaniam et al., 2004).

\subsection{FTIR spectrum accumulation and data processing}

The spectral analysis was carried out by using a PerkinElmer spectrometer equipped with MIR TGS detector (Spectrum 100 Instrument, Perkin Elmer). FTIR spectra of the samples were recorded between 4000 and $450 \mathrm{~cm}^{-1}$ region. Serum samples of $1 \mu$ l were placed on the ATR crystal and were allowed to air dry at room temperature for $10 \mathrm{~min}$ to eliminate the free water contribution to the spectra. Interferograms were averaged for 50 scans at $2 \mathrm{~cm}^{-1}$ resolution. The background spectrum was subtracted from the spectra of the samples automatically. Spectrum 100 (Perkin-Elmer) software was used for all of the data manipulations.

From each sample, at least three different scans, which gave identical spectra, were performed. These replicates were averaged and the averaged spectra for each sample (sample number $=5$ ) were then used for further data manipulation and statistical analysis. The spectra were smoothed over 19 points using the Savitsky Golay algorithm. Then, the spectra were interactively baselined from two arbitrarily selected points. Finally, the spectra were normalized in specific regions for visual comparison of the HHP treated and control samples.

\subsection{Artificial neural network analysis of amide I band}

The amide-I band of the control and pressure treated samples were analyzed and protein secondary structure was predicted through the software developed by Severcan et al. (2004). Neural networks were first trained by using the FTIR spectra of 18 water soluble proteins recorded in water (Severcan et al., 2001). The secondary structures of these proteins were known from X-ray crystallography. Amide I band, namely absorption values from $1600 \mathrm{~cm}^{-1}$ to $1700 \mathrm{~cm}^{-1}$, were preprocessed before applying them to the neural networks. Preprocessing involves normalization and Discrete Cosine Transformation (DCT) of the amide I band of the FTIR spectra. To improve the training of the neural networks, the size of the training data set was increased by interpolating the available FTIR spectra. The NNs were trained using Bayesian regularization. For each structure parameter, a separate NN, the number of inputs (i.e., the number of DCT coefficients and number of hidden neurons) of which were optimized was trained. The trained NNs have standard error of prediction values of $4.19 \%$ for $\alpha$-helix, 3.49\% for $\beta$-sheet and $3.15 \%$ for turns. The 
secondary structure parameters of the new proteins were predicted by applying the preprocessed FTIR data to the inputs of the trained NNs. The details of the training and testing algorithm can be found in Severcan et al. (2004).

\subsection{Virus}

For the HHP virus inactivation study, NADL strain of BVDV1 was chosen as the model virus. BVD virus infectivity was studied by an in vitro plaque assay. For this purpose, pressurized and non-pressurized (control) viruses in FBS were 10-fold diluted using Dulbecco's Minimum Essential Medium (DMEM; Biochrom, Germany). Each dilution of viruses was inoculated $(0.2 \mathrm{~mL})$ in duplicate onto confluent Madin-Darby Bovine Kidney (MDBK) cells previously grown in 24-well plates. Following $1 \mathrm{~h}$ at $37^{\circ} \mathrm{C}$ for attachment of the virus to MDBK cells, the cells were overlaid with $1 \mathrm{~mL}$ of $1.6 \%$ carboxymethylcellulose (CMS; Sigma-Aldrich, USA) to provide a semisolid environment. The wells were daily observed under the cell culture microscope and were fixed with $10 \%$ formaldehyde (Merck, Germany) at the time (approx. 4 days postinoculation) when the plaque formation was detected microscopically. The plaque numbers subsequently were counted for analysis after staining the cells with $0.35 \%$ crystal violet (Merck, Germany).

\subsection{Inactivation of the Bovine Viral Diarrheavirus type 1 on serum using $H H P$}

An original viral suspension with a certain concentration or titer in the fetal bovine serum was prepared to simulate a real blood environment in cryovials. The suspensions were kept in ice bath to prevent further microbial loss. The viral suspensions were assumed to have the same microorganism concentration since they were prepared from the original stock suspension. The samples were equilibrated to $25{ }^{\circ} \mathrm{C}$ prior to the pressure applications. For each pressure level, triplicate experiments were carried out. Commercial fetal bovine serum (Biochrom AG, Germany) was used for the preparation of HHP treated model microorganism. Prior to the dilution of the model microorganism, fetal bovine serum was inactivated with a heat treatment at $56^{\circ} \mathrm{C}$ for $30 \mathrm{~min}$.

\subsection{Statistical analysis}

The differences between the control and pressure treated groups were compared using the Mann-Whitney $U$ Test with the Minitab Statistical Software Release 13,0 program. The statistical results are expressed as mean$\mathrm{S} \pm$ standard deviation. A $P$ value of less than 0.05 was considered statistically significant.

\section{Results}

\subsection{Pressure stability of Bovine Viral Diarrheavirus type 1}

In Fig. 1, the pressure stability of the NADL strain of BVDV1 for $5 \mathrm{~min}$ of application at $25^{\circ} \mathrm{C}$ is presented. The mean initial viral load is $25.333 \times 10^{4} \mathrm{PFU} / \mathrm{mL}$. Therefore,

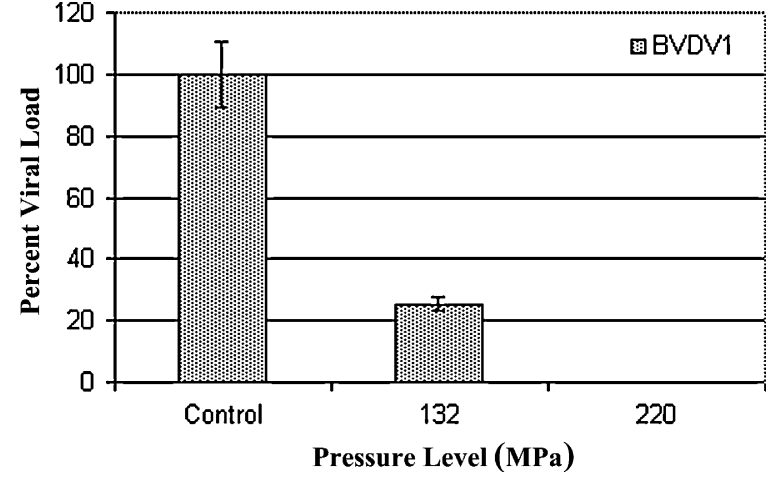

Fig. 1. HHP stability of Bovine Viral Diarrheavirus type 1 at $25^{\circ} \mathrm{C}$ for $5 \mathrm{~min}$.

the viral load after $132 \mathrm{MPa}$ HHP decreases to approximately $25 \%$ of the original virus titer. The model virus exhibits complete inactivation behavior at $220 \mathrm{MPa}$ HHP treatments under the same conditions.

\subsection{Effects of HHP on serum studied by FTIR}

FTIR spectroscopy technique provides useful information about the structure and function of the macromolecular constituents of biological systems at molecular level, which was used, in the current study, in the analysis of the effects of HHP on serum (Dogan et al., 2007; Cakmak et al., 2006, 2011; Toyran et al., 2005).

Fig. 2 shows the average FTIR spectrum of control fetal bovine serum in the $3800-900 \mathrm{~cm}^{-1}$ spectral region. The assignments of the major bands in Fig. 2 are presented in Table 1 . Since the FTIR spectrum of serum is quite complex and consists of several bands originating from the contribution of different functional groups belonging to biomolecules, such as lipids and proteins, the spectra were analyzed for the following regions: $3100-3680 \mathrm{~cm}^{-1}$ for the analysis of proteins, $2840-3000 \mathrm{~cm}^{-1}$ for the analysis of lipids, $1600-1700 \mathrm{~cm}^{-1}$ for the analysis of proteins, and $910-1480 \mathrm{~cm}^{-1}$ for the analysis of the fingerprint region. All the spectra presented in the figures were normalized

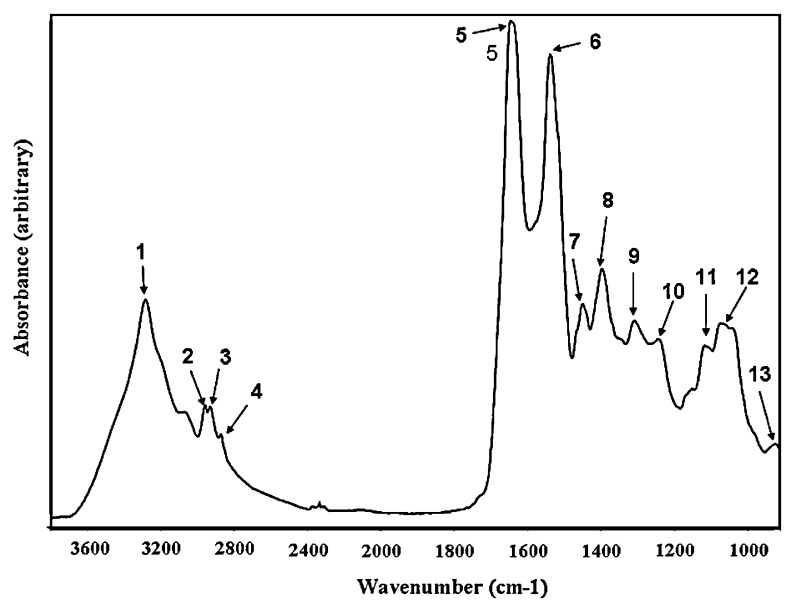

Fig. 2. The general FTIR spectrum of fetal bovine serum in the 3800$900 \mathrm{~cm}^{-1}$ region. 
Table 1

General band assignments of FTIR spectrum of fetal bovine serum based on the literature.

\begin{tabular}{|c|c|c|}
\hline Band number & Wavenumbers $\left(\mathrm{cm}^{-1}\right)$ & Definition of the spectral assignment \\
\hline 1 & 3286 & $\begin{array}{l}\text { Amide A mainly } \mathrm{N}-\mathrm{H} \text { stretching of proteins with the little contribution from } \mathrm{O}-\mathrm{H} \text { stretching } \\
\text { of polysaccharides and intermolecular bonding }\end{array}$ \\
\hline 2 & 2960 & $\mathrm{CH}_{3}$ asymmetric stretch: mainly lipids, with the little contribution from proteins, carbohydrates \\
\hline 3 & 2933 & $\mathrm{CH}_{2}$ asymmetric stretch: mainly lipids, and the little contribution from proteins and carbohydrates \\
\hline 4 & 2873 & $\mathrm{CH}_{3}$ symmetric stretch: mainly proteins, with the little contribution from lipids and carbohydrates \\
\hline 5 & 1650 & Amide I: proteins, mainly $\mathrm{C}=\mathrm{O}$ stretch \\
\hline 6 & 1540 & Amide II: proteins, mainly $\mathrm{N}-\mathrm{H}$ bend and $\mathrm{C}-\mathrm{N}$ stretch \\
\hline 7 & 1452 & $\begin{array}{l}\mathrm{CH}_{2} \text { bending: mainly lipids, with the little contribution from proteins, } \mathrm{CH}_{3} \text { asymmetric bending: methyl } \\
\text { groups of proteins }\end{array}$ \\
\hline 8 & 1399 & $\begin{array}{l}\mathrm{COO}^{-} \text {symmetric stretch: mainly lipids with the little contribution from proteins, } \mathrm{CH}_{3} \text { symmetric bending } \\
\text { methyl groups of proteins }\end{array}$ \\
\hline 9 & 1310 & Amide III: proteins \\
\hline 10 & 1240 & Amide III: proteins; $\mathrm{PO}_{2}{ }^{-}$symmetric stretch: phospholipids \\
\hline 11 & 1116 & C-O-C stretch: lipids \\
\hline 12 & 1075 & $\mathrm{CO}-\mathrm{O}-\mathrm{C}$ symmetric stretch: lipids \\
\hline 13 & 925 & $\mathrm{C}-\mathrm{C}$ or $\mathrm{C}-\mathrm{O}$ stretch: from the skeletal phospholipids head \\
\hline
\end{tabular}
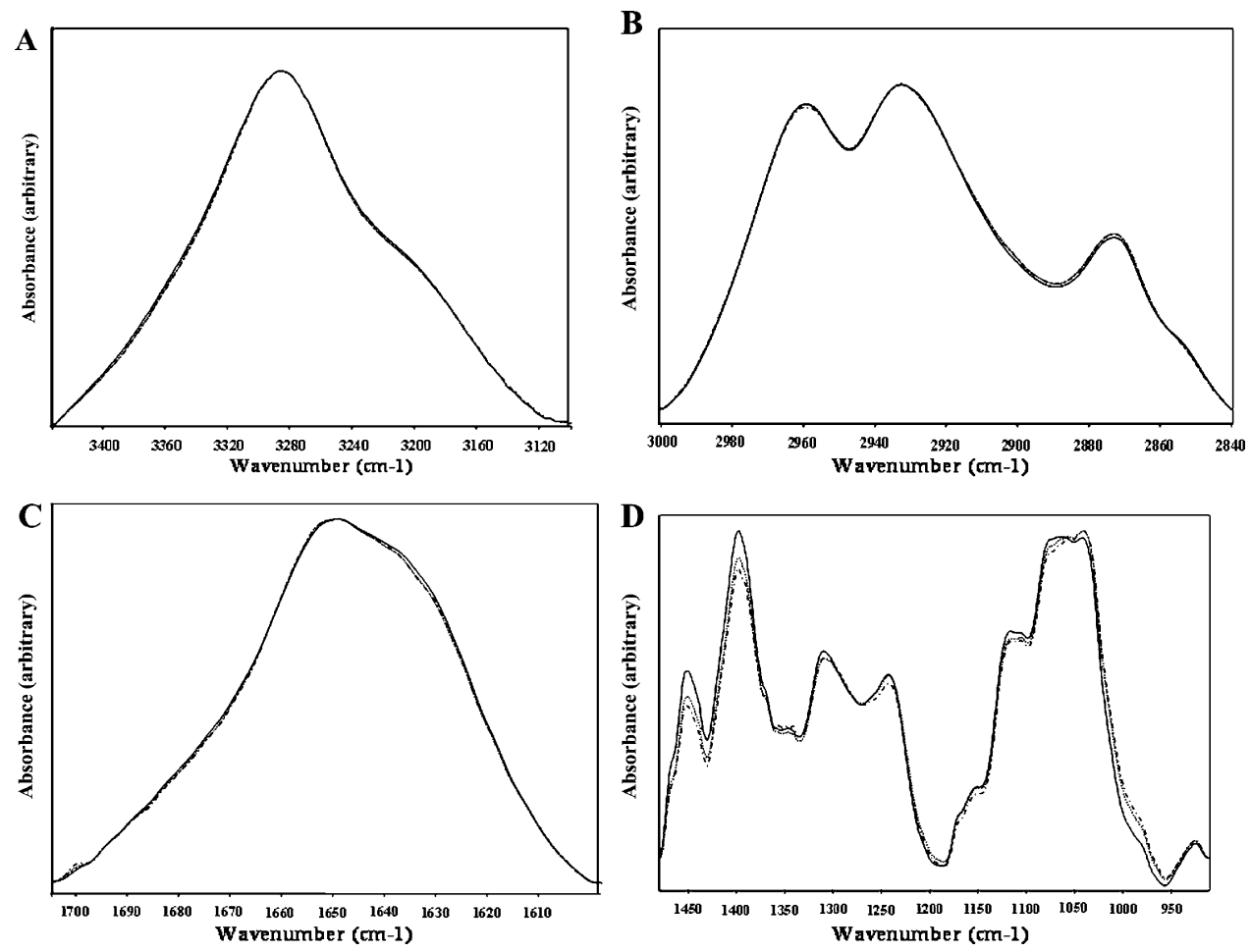

Fig. 3. The average spectra of control (solid line), $132 \mathrm{MPa}$ (dash line) and $220 \mathrm{MPa}$ (dash-dot-dash line) $\mathrm{HHP}$ treated fetal bovine serum at $25^{\circ} \mathrm{C}$ for $5 \mathrm{~min}$ (A) in the $3100-3680 \mathrm{~cm}^{-1}$ spectral region (the spectra were baselined and then normalized with respect to the $3286 \mathrm{~cm}^{-1}$ band and stacked), (B) in the $2840-$ $3000 \mathrm{~cm}^{-1}$ spectral region (the spectra were baselined and then normalized with respect to the $2960 \mathrm{~cm}^{-1}$ band and stacked), (C) in the $1706-1600 \mathrm{~cm}^{-1}$ region (the spectra were baselined and then normalized with respect to the $1650 \mathrm{~cm}^{-1}$ band and stacked) and (D) in the $910-1480 \mathrm{~cm}^{-1}$ spectral region (the spectra were baselined and then normalized with respect to the $1397 \mathrm{~cm}^{-1}$ band and stacked).

with respect to specific selected bands and used only for illustrative purposes. However, in the measurement of the spectral parameters, each original baseline-corrected spectrum belonging to the corresponding control and treated groups was considered separately.

$3100-3680 \mathrm{~cm}^{-1}$ Region. Fig. 3a shows the average FTIR spectra of control and HHP-treated blood cells in the $3100-$ $3680 \mathrm{~cm}^{-1}$ spectral region. The FTIR spectrum in this region consists of amide $\mathrm{A}$ band which has contributions from mainly the $\mathrm{N}-\mathrm{H}$ stretching of proteins with the little contribution from the $\mathrm{O}-\mathrm{H}$ stretching of polysaccharides and intermolecular $\mathrm{H}$ bonding (Melin et al., 2000; Cakmak et al., 2011). All the control and treated spectra have almost the same overlapping absorption bands. No change was observed in the wavenumber, intensity and bandwidth values of the bands, as seen in Fig. 3a.

$2840-3000 \mathrm{~cm}^{-1}$ Region. Fig. 3b shows the average FTIR spectra of control and HHP-treated blood cells in the 2840- 
$3000 \mathrm{~cm}^{-1}$ spectral region. The FTIR spectrum in this region consists of four bands: the $\mathrm{CH}_{3}$ asymmetric stretching band located at $2960 \mathrm{~cm}^{-1}$, has contributions from both lipids and proteins (Cakmak et al., 2006), the $\mathrm{CH}_{2}$ asymmetric and symmetric stretching band located at $2933 \mathrm{~cm}^{-1}$ and $2858 \mathrm{~cm}^{-1}$, respectively, are mainly due to lipids (Severcan et al., 2000), and the $\mathrm{CH}_{3}$ symmetric stretching band located at $2873 \mathrm{~cm}^{-1}$, which mainly monitors proteins (Severcan et al., 2000; Cakmak et al., 2011). The control and HHP treated spectra have almost the same overlapping absorption bands. No change was observed in the wavenumber, intensity and bandwidth values of the bands, as seen in Fig. 3b.

$1600-1700 \mathrm{~cm}^{-1}$ (amide I) Region. Fig. 3c shows the average FTIR spectra of the control and HHP-treated fetal bovine serum in the $1706-1600 \mathrm{~cm}^{-1}$ spectral region. The FTIR spectrum in this region represents the well-known amide I band which has contributions from different protein secondary structural elements (Dogan et al., 2007). It should be emphasized that the absorption spectra presented in Fig. 3c were normalized with respect to specific selected bands, but these spectra were used only for illustrative purposes. However, each original spectrum belonging to the control and treated groups was considered separately during the accurate measurement of the spectral parameters.

$910-1480 \mathrm{~cm}^{-1}$ (fingerprint) Region. Fig. 3d shows the average FTIR spectra of the control and HHP-treated blood cells in the $910-1480 \mathrm{~cm}^{-1}$ spectral region. The bands in this spectral region have contributions from proteins, lipids and carbohydrates in the serum samples. Although the increase in the intensities of the bands at $1450 \mathrm{~cm}^{-1}$ and $1397 \mathrm{~cm}^{-1}$ were found to be statistically insignificant for 132 and $220 \mathrm{MPa}$ HHP treatments, respectively, they showed a marked increase in their intensity upon HHP treatment. A similar trend was also observed for $1310 \mathrm{~cm}^{-1}, 1242 \mathrm{~cm}^{-1}$ and $1116 \mathrm{~cm}^{-1}$ bands whereas the band at $1041 \mathrm{~cm}^{-1}$ shows a decreased intensity for $220 \mathrm{MPa}$ HHP treatment.

\subsection{Analysis of protein secondary structure elements with an artificial neural network algorithm based on FTIR data}

An artificial neural network algorithm was used to predict the relative amounts of several secondary structural elements of serum for different pressure levels. As illustrated in Fig. 4, HHP treatment yields statistically insignificant changes in secondary structure elements.

\section{Discussion}

In this work, we studied the HHP-based inactivation of Bovine Viral Diarrheavirus type 1 on serum and the effect of HHP on the stability behavior of serum components by FTIR spectroscopy for the ultimate purpose of HHP-based inactivation of pestiviral contaminations from patientoriginated serum or commercial preparations.

FTIR spectroscopy made it possible to rapidly and sensitively monitor pressure-induced structural alterations in proteins in untreated, unstained and unfixed whole tissue samples without destroying the native

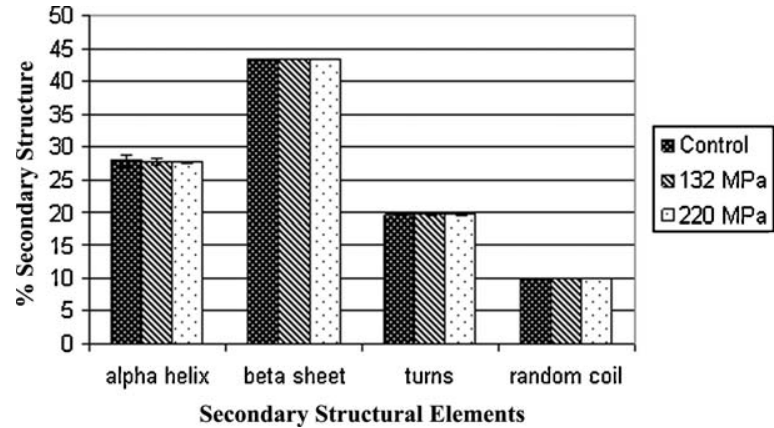

Fig. 4. The effect of HHP on the secondary structural elements of fetal bovine serum studied by the artificial neural network algorithm method.

structure of the proteins. In FTIR studies, the signal intensity and area under the bands give information about the concentration of the related functional groups (Freifelder, 1982). Information about the secondary structural changes was obtained based on amide I band using NN method. This approach, recently, has been successfully applied to tissue and membrane proteins by our groups (Bozkurt et al., 2010; Garip and Severcan, 2010; Cakmak et al., 2011). In our study using this novel method we did not see any HPP-induced secondary structural changes for the proteins. In addition, there is no frequency shift in the lipid bands implying that there is no variation in lipid structure due to the HPP treatment. We also clearly showed that HPP treatment did not change the macromolecular concentration since there is no variation in the area of control and treated groups.

Serum is composed of lipids, proteins and carbohydrates in an aqueous milieu. Carbohydrates and proteins are present in the serum in a dissolved format. Since the carbohydrates in serum are small organic molecules, they are supposed to undergo reversible structural changes within the studied pressure range and, therefore, to remain unchanged in the FTIR spectra. However, macromolecules are only marginally stable under various environmental changes, and mainly proteins are labile to the changes such as pressure. Therefore, they frequently undergo irreversible structural changes in addition to reversible ones. Although lipids are not macromolecules, they frequently form special aggregates in aqueous environments. They are transported in the serum in the form of lipoproteins where lipids are covered by a protein-phospholipid coat. Hydrostatic pressure can alter these macromolecular assemblages. Anton et al. (2003) observed significant changes in the structures of egg Low Density Lipoprotein (LDL) structure in static hydrostatic pressure experiments at 5000 bars. The HHP treated LDL structures were disrupted down to $90 \mathrm{~nm}$ diameter emulsions. The HHP treatments were also observed to generate a homogenization effect on LDL particles which is an advantageous property in forming stable emulsions widely used in food industry. If lipoprotein structures are altered by HHP treatments, their ability to form lipoprotein structures should also change, thus forming dispersed lipoprotein structures with a small diameter. These changes should also change the lipid and protein originated FTIR peaks at $1450 \mathrm{~cm}^{-1}$ and $1397 \mathrm{~cm}^{-1}$. 
BVDV1 was inactivated completely on serum at $220 \mathrm{MPa}$ for 5 min of HHP application. The instability behavior of the model virus was found to be in the same range for another pestivirus, classical swine fever virus, in an earlier study (Freitas et al., 2003). Although virus inactivation studies indicated that for inactivation of some viruses higher pressures were required (Kingsley et al., 2002), in this study $220 \mathrm{MPa}$ was found to be enough to inactivate BVDV1, which is a common contaminant found in commercial serum preparations. Differences between the pressure stabilities of individual proteins and much larger macromolecular assemblages, such as viruses, allow pressure inactivation of serum contaminating viruses in the case of BVDV1.

\section{Conclusion}

The results of the current study indicate that HHP treatment does not cause significant changes in the structure, function, composition and concentration of serum proteins. The results of the current study indicate that HHP treatment at $220 \mathrm{MPa}$ for $5 \mathrm{~min}$ at $25^{\circ} \mathrm{C}$ causes changes in the serum lipoprotein structure, the evidence of which is observed through the changes in the lipid bands. Successful inactivation of BVDV1 was achieved at $220 \mathrm{MPa}$ for $5 \mathrm{~min}$. Therefore, HHP treatment can be used to eliminate BVDV1 and other pestiviruses from serum successfully while leaving serum protein content unaffected.

\section{References}

Anton, A., Martinet, V., Dalgalarrondo, M., Beaumal, V., David-Briand, E., Rabesona, H., 2003. Chemical and structural characterization of lowdensity lipoproteins purified from hen egg yolk. Food Chem. 83, 175-183.

Balasubramaniam, V.M., Ting, E.Y., Stewart, C.M., Robbins, J.A., 2004. Recommended laboratory practices for conducting high-pressure microbial inactivation experiments. Innovat. Food Sci. Emerg. Tech. 5, 299-306.

Beltrami, E.M., Williams, I.T., Shapiro, C.N., Chamberland, M.E., 2000. Risk and management of blood-borne infections in health care workers. Clin. Microbiol. Rev. 13, 385-407.

Bozkurt, O., Severcan, M., Severcan, F., 2010. Diabetes induces compositional, structural and functional alterations on rat skeletal soleus muscle revealed by FTIR spectroscopy: a comperative study with EDL muscle. Analyst 135, 3110-3119.

Bradley, D.W., Hess, R.A., Tao, F., Sciaba-Lentz, L., Remaley, A.T., Laugharn, J.A. Jr., Manak, M., 2000. Pressure cycling technology: a novel approach to virus inactivation in plasma. Transfusion 40, 193-200.

Cakmak, G., Togan, I., Severcan, F., 2006. 17ß-Estradiol induced compositional, structural and functional changes in rainbow trout liver, revealed by FT-IR spectroscopy: A comparative study with nonylphenol. Aquat. Toxicol. 77, 53-63.

Cakmak, G., Zorlu, F., Severcan, M., Severcan, F., 2011. Screening of protective effect of amifostine on radiation-induced structural and functional variations in rat liver microsomal membranes by FT-IR spectroscopy. Anal. Chem. 83, 2438-2444.

Ceylan, C., Severcan, M., Bozoglu, F., Severcan, F., 2009. Evaluation of high hydrostatic pressure effects on bovine red blood cells and platelets. High Pressure Res. 29, 358-368.

Dogan, A., Ergen, K., Budak, F., Severcan, F., 2007. Evaluation of disseminated candiditiasis on an experimental animal model: A Fourier transform infrared study. Appl. Spectrosc. 61, 199-203.
Freifelder, D., 1982. Applications to Biochemistry and Molecular Biology. In: Physical Chemistry, Freeman, W.H. and Company, New York (Chapter 14).

Freitas, T.R.P., Gaspar, L.P., Caldas, L.A., Silva, J.L., Rebello, M.A., 2003. Inactivation of classical swine fever virus: association of hydrostatic pressure and ultraviolet irradiation. J. Virol. Methods 108, 205-211.

Garip, S., Severcan, F., 2010. Determination of simvastatin-induced changes in bone composition and structure by Fourier transform infrared spectroscopy in rat animal model. J. Pharm. Biomed. Anal. $52(4), 580-588$.

Hayashi, R., 1995. Advances in high pressure processing technology in Japan. In: Gaonkar, A.G. (Ed.), Food Processing: Recent Developments. Elsevier, London, pp. 185-195.

Hoover, D.G., Metrick, C., Papineau, A.M., Farkas, D.F., Knorr, D., 1989. Biological effects of high hydrostatic pressure on food microorganisms. Food Technol.-Chicago 43, 99-107.

Jurkiewicz, E., Villas-Boas, M., Silva, J., Weber, G., Hunsmann, G., Clegg, R.M., 1995. Inactivation of simian immunodeficiency virus by hydrostatic pressure. Proc. Natl. Acad. Sci. U.S.A. 92, 6935-6937.

Kingsley, D.H., Hoover, D.G., Papafragkou, E., Richards, G.P., 2002. Inactivation of hepatitis A virus and a calicivirus by high hydrostatic pressure. J. Food Protect. 65, 1605-1609.

Knorr, D., 1993. Effects of high-hydrostatic-pressure processes on food safety and quality, Food Technol-Chicago. June, 156-161.

Makoschey, B., Gelder, P.T.J.A.v., Keijers, V., Goovaerts, D., 2003. Bovine viral diarrhea virus antigen in foetal calf serum batches and consequences of such contamination for vaccine production. Biologicals 31, 203-208.

Matser, A.M., Van Der Ven, C., Gouwerok, C.W.N., De Korte, D., 2005. Highpressure processing for preservation of blood products. High Pressure Res. 25, 37-41.

Melin, A.M., Perromat, A., Deleris, G., 2000. Pharmacologic application of Fourier transform IR spectroscopy: in vivo toxicity of carbon tetrachloride on rat liver. Biopolymers 57, 160-168.

Nuttall, P.A., Luther, P.D., Stott, E.J., 1977. Viral contamination of bovine foetal serum and cell cultures. Nature 266, 835-837.

Pares, D., Saguer, E., Toldra, M., Carretero, C., 2000. Effect of high pressure processing at different temperatures on protein functionality of porcine blood plasma. J. Food Sci. 65, 486-490.

Severcan, F., Toyran, N., Kaptan, N., Turan, B., 2000. Fourier transform infrared study of the effect of diabetes on rat liver and heart tissues in the $\mathrm{C}-\mathrm{H}$ region. Talanta $53,55-59$.

Severcan, M., Severcan, F., Haris, P.I., 2001. Estimation of protein secondary structure from FTIR spectra using neural networks. J. Mol. Struct. 565-566, 383-387.

Severcan, M., Haris, P.I., Severcan, F., 2004. Using artificially generated spectral data to improve protein secondary structure prediction from Fourier transform infrared spectra of proteins. Anal. Biochem. 332, 238-244.

Silva, J.L., 1993. In: Winter, R., Jonas, J. (Eds.), In High Pressure Chemistry, Biochemistry and Material Sciences NATO ASI series, 401. Kluwer Academic Publishers, Dordrecht, The Netherlands, pp. 561-578.

Tedford, L.A., Smith, D., Schaschke, C.J., 1999. High pressure processing effects on the molecular structure of ovalbumin, lysozyme and $\beta$ lactoglobulin. Food Res. Int. 32, 101-106.

Toldra, M., Davila, E., Saguer, E., Fort, N., Salvador, P., Pares, D., Carretero, C., 2008. Functional and quality characteristics of the red blood cell fraction from biopreserved porcine blood as influenced by high pressure processing. Meat Sci. 80, 380-388.

Toyran, N., Zorlu, F., Severcan, F., 2005. Effect of stereotactic radiosurgery on lipids and proteins of normal and hypoperfused rat brain homogenates: a Fourier transform infrared spectroscopy study. Int. J. Radiat. Biol. 81, 911-918.

Wuytack, E.Y., Diels, A.M.J., Michiels, C.W., 2002. Bacterial inactivation by high-pressure homogenization and high hydrostatic pressure. Int. J. Food Microbiol. 77, 205-212.

Zitzmann, N., Mehta, A.S., Carrouee, S., Butters, T.D., Platt, F.M., McCauley, J., Blumberg, B.S., Dwek, R.A., Block, T.M., 1999. Imino sugars inhibit the formation and secretion of bovine viral diarrhea virus, a pestivirus model of hepatitis $C$ virus: implications for the development of broad spectrum anti-hepatitis virus agents. Proc. Natl. Acad. Sci. U.S.A. 96, $11878-11882$ 